\title{
Commentary
}

Michael T. Davis*

\section{"We Want What Everybody Else in an Advanced Society Seems to Have": Why Chinese Democracy Is Inevitable}

\begin{abstract}
With the recent pro-democracy protests in Hong Kong, here is one of the most intriguing questions of our time - what is China's political destiny? For some, the answer seems self-evident: world domination. Martin Jacques and many other China watchers say it is not "if" but "when China rules the world". But the burning question is, how will China rule itself? How will it survive as a stable and centralized state through its economic and global make-over as a superpower? What will the political future of this vast and rapidly evolving nation look like? Will China have a democracy? Perhaps the answers to these questions can be found in another time and place - in Britain during the socalled long eighteenth century (1688-1832) - where we can see parallels between the forces that helped transform Britain into the global superpower of the nineteenth century and those that underpin China's modern-day transformation. This article argues that these forces will set China on the path to democracy in the same way they helped change the political dimensions of Britain.
\end{abstract}

Keywords: Chinese democracy, eighteenth-century Britain

DOI 10.1515/ngs-2015-0001

Early in the nineteenth century, Napoleon Bonaparte reputedly uttered the words: "When China wakes, it will shake the world." After 200 years, this vision is proving to be both pertinent and prophetic. For some contemporary commentators, China's future seems certain, if not pre-determined: China will be the world's next superpower and the dominant economic powerhouse, as it leads the so-called Asian Century over the next 100 years. What we are witnessing is a historic shift in the global balance of power, a view which is validated by statistics and which makes sense of the trite cliché that size does matter.

*Corresponding author: Michael T. Davis, School of Humanities Griffith University, Gold Coast, Australia, E-mail: m.davis@griffith.edu.au 
China is the world's most populous country, with nearly 1.4 billion people and rising, giving it tremendous and seemingly infinite human resources to drive forward development and to produce a domestic market of unprecedented size. And these people are generally living longer lives than many people in the West: for instance, The New York Times reported in 2011 that a child born in Shanghai today is expected to live nearly 3 years longer than one born in America. (Kristof 2011). In 2013, China also flexed its economic muscles by overtaking the United States as the largest trading nation in the world, with the Asian nation importing and exporting \$3.87 trillion in goods. Not surprisingly, China has its own visions for its economic future that include the renminbi becoming the world's reserve currency in place of the American dollar. There are even plans to send a mission to Mars and robotic explorations of other planets by 2050, following the successful "soft-landing" of a spacecraft on the Moon by the Chinese in December 2013 (Harvey 2013).

It seems almost self-evident, almost inevitable, that China is set to change history by conquering the world and beyond in one way or another. Yet this should not come as a surprise. China is historically an extraordinary country, with more than 4,000 years of recorded history and a long list of world-leading achievements. Without the Chinese, the world as we know it would not be the same. We are indebted to them for what Joseph Needham called the "Four Great Inventions": paper, printing, gunpowder and the compass (Needham 1956). There is also silk weaving, porcelain, wheelbarrows, the kite, suspension bridges, noodles, the banknote and even nail polish - to mention just a few that are among the list of Chinese inventions. And we should not forget that some public celebrations would be rather dull affairs without fireworks, which first appeared during the Song Dynasty in the eleventh century. Despite such remarkable contributions to humankind, China is set to make perhaps an even greater impact on history during the course of the twenty-first century. All the indications are that China will take on a new, elevated global role and that this will necessitate an important change in the collective mindset of the West. Indeed, this is a momentous milestone moment in history and as Martin Jacques notes: "We stand on the eve of a different kind of world, but comprehending it is difficult: we are accustomed to dealing with the paradigms and parameters of the contemporary world that we inevitably take for granted, believing they are set in concrete rather than themselves being the subject of longer-run cycles of historical change" (2012:11-12). For Jacques and many other China watchers, it is not "if" but "when China rules the world" (cf. Fenby 2014).

But the burning question is, how will China rule itself? How will China survive as a stable and centralized state through its economic and global makeover as a superpower? What will the political future of this vast and rapidly 
evolving nation look like? Perhaps the answers to these questions can be found in another time and place - in Britain during the so-called long eighteenth century (1688-1832), where we can see parallels between the forces and processes that helped transform Britain into the global superpower of the nineteenth century and those that underpin China's modern-day transformation. As a result of the agencies of change that took place during the long eighteenth century, Britain had the world's most vibrant economy in the nineteenth century and it was able to develop the largest empire in history. This vast empire, on which it was said that the sun never sets, facilitated the spread of British institutions and ideals to such far-flung places as Canada, India and Australia. One of those ideals was democracy and it was during the long eighteenth century that the foundations were laid for the progressive democratization of British society, especially after the Great Reform Act of 1832 (Ertman 2010).

Interestingly, one of the discussion points about China is whether or not the nation and its people will be put on the path of democracy. Many Western observers inappropriately approach this topic, one way or another, with a normative stance that places Western-style democracy as the highest form of political evolution. But to argue that China will have a democratic future should not imply any level of Western superiority or be loaded with Eurocentrism. In fact, it is reasonable to accept that "democracy with Chinese characteristics" will continue to unfold into reality and China is likely to develop its own version of democracy in the same way that Russia and Japan have done (Cho 2009). It is also important to acknowledge that we are comparing diversely distinct countries in different historical periods. Britain during the long eighteenth-century and modern-day China are socially, politically and culturally unique. However, despite these dissimilarities, the comparison is not a trite analogy and not one lost for at least some Chinese. Li Daokui, Professor of Economics at Tsinghua University and former adviser to China's central bank, is reported as saying: "We want to learn from the British model .... Today's leaders in China are looking carefully at the British style of political change over the last 400 years" (EvansPritchard 2013). For Li, Britain during the eighteenth century provides a map for charting the waters of reform and avoiding the hazards of revolution. This reflection by the Chinese on the British past implicitly acknowledges that the developments that took place in Britain, which created a liberal society, are likely to have a similar impact on China's politics in the future. Just as the forces of change in eighteenth-century Britain paved the way for democracy, so too will those similar agencies help determine and shape the political destiny of China. As Jacques notes: "In the long run it seems rather unlikely, given the underlying pressures for democracy that exist within increasingly sophisticated, diverse and 
prosperous societies, that China will be able to resist the process of democratization” (2012: 272).

This process will undoubtedly be a significant turning point in the sweeping narrative of Chinese history, in which China is seen as having no democratic heritage from its foundation some 5,000 years ago to the fall of the Qing Dynasty in 1911. It is true that the country's dynastic political traditions were underpinned by notions of state sovereignty rather than popular sovereignty, but this political template cannot be entirely superimposed on China's past and its Confucian foundations. While Confucianism can support an authoritarian government, it also has aspects that could cushion democratic ideas and this has informed the history of China. For instance, Sun Yat-sen - the leader of the 1911 overthrow of the Qing Dynasty - looked back to the ancient Confucian philosopher, Mencius. For Sun, "Mencius is really the ancestor of our democratic ideas" (Bell and Chaibong 2003: 9). This is an important reflection given the renaissance of Confucianism and decline of Marxism in contemporary China (Fan 2011). For instance, since the 1990s school children have again been taught the works of Confucius from the sixth-century BC and the philosopher's birthday has been the focus of celebrations. Significantly, in China's bureaucratic heart of Beijing in September 2010, the first celebration of Confucius's birthday took place since the establishment of Communist China in 1949 (Branigan 2010). At a provincial level, we can also see the revival of Confucianism in relation to local government. For example, an assessment of Confucian values, such as filial piety and family responsibility, is now made of Communist Party officials seeking promotion in the province of Henan (Bell 2008: 9).

But it might be argued that Britain in the long eighteenth century - unlike modern-day China - at least had some semblance of grassroots democratic practices, not just philosophical musings, ahead of the changes that came with and followed the Reform Act of 1832. While democracy was not a word used for most of the eighteenth century, by the mid-nineteenth century it was an expectation for many which was partially informed by popular awareness of and engagement in democratic practices of the previous century. The right to vote in eighteenth-century Britain was one based upon property qualifications, which meant that about $10 \%$ of the total adult population had the franchise. However, the common people - those who did not meet the property requirements to cast a vote at an election - were still directly involved in the political process and can be seen as active citizens. Elections "were an opportunity for the populace to turn the world upside down, if only for a short period" and crowd actions, such as election riots, were an integral part of Hanoverian politics that "formed a vital part of the legitimacy of the electoral process” (Randall 2006: 185). As Frank O'Gorman has noted, the involvement of the common people in crowd actions 
during elections "maintained the illusion of popular participation and the tradition of unrestricted expression of opinion" (1989: 130). We also find actual democratic practices in the eighteenth century that would have given some people a familiarity with democracy. For instance, the London members of the livery companies, which were basically trade guilds, elected the City's four members of Parliament and nominated candidates for Lord Mayor and Sheriff (Doolittle 1982). While the liverymen were middle-class master craftsmen, the working classes also had their own taste of democracy when the London Corresponding Society (LCS) was formed in 1792. The Society was Britain's first truly working-class political club and its primary objective was electoral reform, including an extension of the franchise. Importantly, the LCS had its own internal system of democracy that "anticipated the reformed constitutional government they advocated" and "demonstrated that members of the LCS those tradesmen, mechanics and shopkeepers excluded from the British polity had the faculties and propensities for active citizenship and political virtue" (Davis 2008: 30).

These experiences of democracy - however illusionary or tenuous - would have whetted the political appetites of Britons. Interestingly, there have also been tokens of democracy in China that have given the masses a taste of enfranchisement and dispel the myth that the Chinese have never been acquainted with democratic practices. We can look as far back as February 1913, when China held its first (and only) national election after the fall of the Qing Dynasty. Following victory at this election of the Kuomintang, a party founded by Sun Yat-sen and Song Jiaoren, provincial elections became a common feature of China's political landscape, engaging over 36 million people in 1918 alone. In fact, so common were elections during the Republican period that it has been described as "politically more democratic than many comparable regimes in Europe at the time" and by 1944 some Western observers looked to China as the "nation which will carry the light of democracy to the millions of East Asia” (Dikötter 2008: 7, 20-23). More recently, democratization has occurred through elected villager's committees in provincial China. These elections have been contested by multiple candidates, with ballots held in secret and on the basis of one person, one vote. And it is democratization on a grand scale: since the first legislation allowing village elections was passed in 1988, there have been nearly 1 million elections in some 600,000 villages. Much of China's largest sector of the population - villagers - is now familiar with the concept and practice of democracy (Brown 2011; Zhou 2012: 13-17). Chinese leaders can point to the village elections as an outward commitment to their strategy of democratization, which has been further formulated in the White Paper issued in 2005 on the Building of Political Democracy in China (State 
Council Information Office 2005). Irrespective of any Western cynicism or criticism of Communist visions for democracy in China, it seems apparent the political leaders of China know that an expansion of political rights is an inevitable, if not a desirable eventuality. The key historical forces that defined and shaped the long eighteenth century in Britain are also present in modernday China. These are forces that cannot be ignored or resisted, and just as they set Britain on the path of democracy so too will they have a modernizing impact on China's politics in the future.

One of the main markers of modernization in both eighteenth-century Britain and modern China is the shift away from subsistence agriculture and the development of an industrial economy. Economists who follow W.W. Rostow's model of economic growth would identify both countries in their respective historical periods as moving through the stage of "take-off" to a "drive to maturity" (1960). And these are moves of resounding proportions and uncanny parallels. In the seventeenth century and for much of the eighteenth century, Britain was an agrarian society. But, Britain became the world's industrial powerhouse as the eighteenth century progressed into the nineteenth century, with flourishing textile, iron and shipbuilding industries leading the way. Today, China has been remodelled in a similar way, shifting from an agricultural backwater to a booming industrial giant. Just as Britain underwent more of an industrial "evolution" than an industrial "revolution" (Crafts 1985), we can also point to China's industrial growth as a process that evolved over the last four decades since Deng Xiaoping initiated a series of economic reforms that captured the Chinese desire to modernize and catch up to the West (Tisdell 2009). With its seemingly unlimited supply of cheap labour, China is now the world leader in many areas of manufacturing and the label "made in China" whether applied pejoratively or not - is a phrase that captures the dominant reality of the present and the future.

Of course, both Britain's industrialization and that of China were underpinned by almost insatiable demands for natural resources. After James Watt patented a steam engine in 1781 that could produce continual rotational action, steam became the moving force behind the increasing number of factories in Britain - those "dark Satanic mills" that William Blake saw as destroying the foundations of society and nature. With steam engines needing heated water from coal-fuelled fires, coal mines were barely able to keep up with the demand from British industries during the long eighteenth century. But China has taken this consumption to another level, with its use of fossil fuels about four times that of the world's second largest user, the United States. According to a report from the United Nations Environment Program, "China's dramatic economic growth over the past few decades has increased demands for natural resources 
within and beyond the country in ways that are unprecedented in human history" (Li 2013). Not surprisingly, environmental degradation is one of the most significant symptoms of industrialization. Historians generally acknowledge that the Industrial Revolution in Britain was one of the negative turning points in environmental history and was, in many ways, the beginning for some of the key issues we face today, such as water and air pollution (Clapp 1994; Simmons 2001). By the end of the long eighteenth century, the environmental conditions in Britain's cities were horrendous: “And what cities! It was not merely that smoke hung over them and filth impregnated them, that the elementary public services - water-supply, sanitation, street-cleaning, open spaces etc - could not keep pace with the mass migration of men into the cities" (Hobsbawm 1968: 67-68). This could be a description of many cities in modern-day China, where waste management is often unable to cope with the growth in urban population and where air pollution is implicated in significant loss of life expectancy (Wang and Wang 2013; Pope and Dockery 2013). Worryingly, with rapid rural industrialization, it is not just China's urban population that faces the dangers from environmental damage. Some small communities near polluting factories have even been dubbed "cancer villages" due to the extraordinarily high rates of cancer among their residents (Kaiman 2013).

As concerns about the environment and civil rights increase among the Chinese population, there is a growing awareness of the power to protest against government decisions. The pro-democracy demonstrations that began in Hong Kong in September 2014 are important in this context. They have been described as "the best-documented social movement in history" due to the role played by social media in fuelling and informing the actions of protesters (Kaiman 2014). But they are much more than a sensational social media event. The Hong Kong protests are a crystal ball through which to view China's political future. For most commentators in the Western media, the view in the crystal ball is dark. Reinforced by images of riot police and tear gas, these commentators see the response of the Hong Kong authorities - backed by Beijing - as indicative of the Chinese government's antipathy towards democracy and as evidence that political freedom will never be a part of China's future. And comments like the following from Laura Cha, a prominent Hong Kong businesswoman and politician, do not soften Western cynicism about the prospects for democratization in China: "African-American slaves were liberated in 1861 but did not get voting rights until 107 years later. So why can't Hong Kong wait for a while?” (Tharoor 2014). But the Hong Kong protests are, in fact, affirmation that China will democratize. We can see in Hong Kong's present a prophetic and positive snapshot for China's democratic future. The youth of Hong Kong are ethnically Chinese but generally they are not politically or economically Chinese. Young 
Hong Kongers have achieved a level of economic freedom that basically allows them the time to attain political awareness as well as political expectations. The words of one protester capture perfectly this political awakening that informs the Hong Kong demonstrations: "Our peaceful democracy demonstration has demolished the myth that this is a city of people who care only about money. Hong Kongers want political reform .... The post-90s generation is growing up in a vastly changed city from that of our parents and grandparents. Earlier generations, many of whom came here from mainland China, wanted one thing: a stable life. A secure job was always more important than politics .... The people of my generation want more. In a world where ideas and ideals flow freely, we want what everybody else in an advanced society seems to have: a say in our future" (Chi-Fung 2014). Similar sentiments and outlooks will develop on mainland China, as the once peasant-dominated society transforms into a more affluent and, in turn, a more politically-conscious citizenry. And, as this social transformation unfolds in the decades ahead, we can expect the recent scenes from Hong Kong to become commonplace throughout China and there will be greater popular demands for political rights.

Of course, the Chinese Communist Party has immense forces of law and order at its disposal to deal with any burgeoning reform movement. But there have been significant instances of popular resistance winning concessions from the government. In July 2012, for instance, thousands of residents in Qidong took to the streets to protest against an industrial waste pipeline project that they feared would pollute the city's water - and they won (Macleod 2012). It is worth bearing in mind that there are far more protests in China that lose rather than win, which was also the case in eighteenth-century Britain. But popular unrest is a barometer to measure the level of grassroots pressure in a society. It is a form of self-expression that bears witness to the critical discontent among the common people to their government's practices. The eighteenth century in Britain can be properly described as "an age of riot" (Randall 2006: 303), a time when Benjamin Franklin observed in 1769 the existence of "riots in the country about corn; riots about elections; riots about workhouses; riots of colliers; riots of weavers; riots of coalheavers; riots of swayers; riots of Wilkesites; riots of government men; riots of smugglers" (Franklin 1907: 239). It seemed that nearly everyone in Britain was protesting about nearly everything and the same reflection is true of modern-day China. In fact, China experiences far more protests than is generally recognized and these demonstrations are motivated by concerns that range from the environment and social problems to religion and political justice. China is experiencing its own "age of riot", in which "socially motivated urban and rural protests have steadily increased in frequency, expanded in size, diversified in terms of their participants' backgrounds, 
enlarged in geographical coverage, last longer and displayed higher levels of violence" (Chung, Lai, and Xia 2006: 3).

One key area of contention common to both urban and rural Chinese in recent years has been domestic land grabbing by the government to continue the nation's tremendous economic and industrial leaps. Under the pursuit of development, domestic land expropriation in China has become one of the defining features of industrialization and urbanization (Zhoa and Webster 2011; Siciliano 2013). This is particularly true in provincial China, where vast tracts of land are being seized by local authorities driven by the revenue imperative. The peasants, who held common rights to the land, are often given insufficient compensation while significant profits are reaped by local authorities from commercial and industrial developments. This is a somewhat familiar story in the pages of British history during the long eighteenth century. Between 1750 and 1830, common lands were privatized to enhance agricultural productivity under more than 4,000 Enclosure Acts passed by the British Parliament. With approximately 6.8 million acres of land across England alone subjected to enclosure, there was extensive displacement of peasants from rural areas into the industrial cities (Neeson 1993). This experience often stirred discontent among the peasantry and rural protests became a fairly common way of pushing back against the government (Hammond and Hammond 1987: 71-96). And there are some strikingly similar protests going on in China today, all of which have the Chinese Communist Party worried about the potential for revolt by dispossessed peasants (Davis 2013).

Interestingly, recent research has shown that Chinese citizens tend to express the highest levels of satisfaction with the central government and are least content with local authorities (Saich 2011). This is far from surprising given the "local" world view that many villagers still maintain and, for some, their protests are to a certain extent de-politicized. In one Henan village, a local peasant whom I met in February 2014 has seen most of his village reduced to rubble during the previous year to make way for a new commercial development. In protest against the sum of compensation being offered to him, he remains defiantly in the house he called home for the previous 15 years. When asked if he cared about politics, the answer was a resounding "no".

Yet - perhaps without knowing it - this peasant is asserting his political rights against what is seen as the arbitrary powers of authority, in a way similar to that exerted by the common people in Britain during the long eighteenth century. However, social unrest is unlikely to ripen into a sustained political movement unless connections between disaffected individuals and groups are forged. Urbanization - that dominant, enduring symbol of both British and Chinese industrialization - plays a pivotal role in crystallizing discontents. By 
the time the long eighteenth century was drawing to a close, about $40 \%$ of Britain's population was living in urban areas and London was the world's largest city with a population of around 1.5 million (Bairoch and Goertz 1986). China is now taking what Britain did 200 years ago to a whole new level, at a much faster pace and on a much larger scale. Historically, familiarity with urban life has deep roots in China's past - stretching back to the great ancient cities of Kaifeng and Luoyang and the flourishing capitals of Beijing and Nanjing during the Ming dynasty (Lincoln 2012). But for the first time in Chinese history, it was announced in 2012 that the majority of its population lived in cities rather than rural areas - about 690 million people who were then considered to be city dwellers (Page et al. 2012). In the long eighteenth century, the essence of urbanization was the townscapes of London and the northern industrial cities of Birmingham, Liverpool and Manchester. Today, in spatial geography terms, China has redefined the essence of urbanization with extraordinary urban developments, from "ghost cities" such as Dongguan and Tianducheng (replete with a faux Eiffel Tower) to the booming metropolises of Shanghai, Beijing and Guangzhou.

In Britain during the long eighteenth century, urbanization went hand in hand with economic growth as the economy quadrupled over the course of the period (Maddison 2007). Although the impoverished megacities of Latin America are proof that urbanization and economic expansion are not necessarily complimentary, China envisages its cities will be like those in Britain some 200 years ago: the drivers behind dominating the global economy. But, just as urbanization brought significant social challenges to the British in the long eighteenth century, so too will the Chinese be faced with increasingly difficult issues to address such as urban housing, sanitation, pollution and public health. Amidst these challenges will emerge a political opportunity that will foster calls for democracy and political reform. Cities bring people together, to discuss, to congregate and to share common interests. The long eighteenth century was an "associational world", where people joined together in clubs and societies that catered for their tastes whether it was bee-keeping or religion, science or politics (Black 1963; Clark 2000). Importantly, political reform societies like the LCS were made viable in part because they could attract sufficient members from the expanding city populations. They also benefited from improved communications and transport during the long eighteenth century. Better roads, a more efficient postal system and expansion of the press were all features of Britain at this time, and they were features that political groups used to connect with like-minded citizens and distribute ideas of democracy.

If such a connection of like-minded citizens is to take place anywhere in the world today, it is China that has the platform laid. Superfast trains and 
impressive highway systems are bringing people together more easily. There is also the rapid increase in private car ownership in the last two decades in China, transforming it from the so-called country of bikes to a nation with more than 51 million automobile drivers (Huang 2011). The environmental impact of this huge rise in car ownership is well accounted but the potential political implications are not so recognizable. The building of roads and the driving of cars is not a phenomenon confined just to the cities - everywhere in China is experiencing this transport revolution. In rural areas, it once could take days to traipse from one village to the next. Today, the transport revolution is creating a communications revolution as one-time isolated villages and villagers are now able to connect more efficiently. As this communications revolution in all its facets improved roads, more cars, telecommunication improvements and access to the Internet, despite censorship control that is failing (King et al. 2013) - continues to unfold in China, one of the most important facilitators of political change will be fostered: the spread of ideas. In the eighteenth century, the ideas of freedom that came out of America following independence in 1783 and the concepts of "liberty, equality and fraternity" that emanated from the French Revolution travelled to Britain, across into the Atlantic world and beyond (Armitage and Subrahmanyam 2010). The global entanglement of the period made the spread of ideas impossible to control. But the British government tried. It recognized that the scattering of ideas was a greater threat to the status quo than those who created the ideas, often prosecuting the booksellers and printers of radical writers rather than the writers themselves. Ironically, in trying to stamp out the movement of radical thoughts, prosecution tended to highlight and promote the very ideas that the government tried to suppress, galvanizing the people in their pursuit of reform (Davis 2005). China will inevitably face a similar challenge from ideas critical of government practices and policies. Although the twenty-first century is earmarked as the "Asian Century" and China is at the helm, the economic future of the Chinese will be inextricably linked to the West - a contemporary global entanglement that will encourage popular interest in Western ideas. Into this matrix must be added the many Chinese tourists who travel overseas as well as the huge numbers who study abroad. Research has shown that Chinese students studying in the West actually change their practices as they learn from Western learning cultures (Jin and Cortazzi 2006). Similarly, some of those Chinese will return home infused with notions of political rights and freedoms.

But notions will only go so far towards making a change and time remains the greatest of all transformative forces. It took the long eighteenth century for the making of a politically-conscious working class in Britain, as told in the seminal work of E.P. Thompson (1963). Slowly but progressively they became 
aware of their rights, expressed their discontents and in the end they won. As China moves away from its peasant past to its urban working-class and middleclass future, we will also witness the making of political consciousness among its citizens. The structural changes to China's society that accompany industrialization, urbanization and economic expansion will result in the disappearance of the once dominant world of the peasant. As that world vanishes from view, there will not only be a loss of villages but also what can be called "village mentalities". In a process identified by Ronald Inglehart in the West as the "silent revolution" of post-materialism (1977), more and more Chinese will have the capacity to devote the time once spent on subsistence and survival to issues beyond the local, such as the environment and politics. This new cultural mindset will be an evolution - just as economic maturity can take 50-100 years, so too will political maturity. It will take generations, but even the current generation of Chinese youth is showing a fresh, open-eyed view of the future (Werbel 2013). You can see in some of China's airports the high-end Western fashion stores, which are obviously catering for more than just international visitors. You can see in the clothes and latest electronic gadgetry owned by some Chinese youth their middle-class attainments or at least their aspirations to be socially mobile. But will economic freedom and upward mobility be enough for this generation or those that follow? Or, will they be like the English working classes of the long eighteenth century and demand more of a say in the political present and future of their nation? Perhaps this is a dream; but Xi Jinping is basing China's future around the so-called Chinese Dream, an ideology that is intended to rejuvenate the nation and improve the livelihoods of people. Xi wants Chinese youth "to dare to dream, work assiduously to fulfill the dreams and contribute to the revitalization of the nation" (Yang 2013). Some are dreaming of democracy and the lessons from Britain in the long eighteenth century tell us that this dream will be an inevitable reality.

But what will this future political reality for China look like? What sort of democracy will China have? It will be a democracy that is deliberately intended to be different from Western-style liberal democracies. In theory and to some extent in practice, China's version of democracy will embody the idea of "the masses keeping watch over bureaucracy under the autocratic guidance of a national leader" (Zhou 2012: 13). Of course, there are some inherent anomalies and challenges in blending ideas of democracy with autocracy and this is one of the fundamental reasons for Western cynicism about the commitment of Chinese leaders to democratic reform. But we should not discount China's democratic future because the democracy that will emerge has this unique, non-Westernstyle foundation. As Jacques notes, we should not assume China will have the same democratic structures as the West, since the "form of democracy varies 
greatly according to the history, traditions and culture of a society" (2012: 272). What is important in the democratic future of China is its people will have more say in the political system and, by implication, there will be improvements in political transparency, the rule of law and other notions that are considered familiar and fundamental in Western democracies. The often-quoted concept of "the people as the masters of China" will become a reality, whether that is in the form of a dangnei minzhu (intra-party democracy) or what Brantly Womack calls “socialist democracy" (Womack 2005: 140-41). While some scholars argue that the collapse of socialist states is inevitable and that a party-state system cannot accommodate democratic concepts, still others point to the potential vitality of intra-party democracy (Lam 2011). By necessity, the intra-party system will need to be more transparent, more efficient and engage the people more proactively than the current political system in China. As Zhou states: "If the influence of the people becomes stronger and more effective in a party-state, one can say that the party-state has become more democratic" (2012: 16). If and when China reaches this political destiny, it will achieve what everybody else in an advanced society seems to have.

Acknowledgement: The author would like to thank Professor Harry Dickinson of the University of Edinburgh for his thoughts on this article.

\section{References}

Armitage, D. and Subrahmanyam, S. eds. 2010. The Age of Revolutions in Global Context c. 1760-1840. Basingstoke: Palgrave Macmillan.

Bairoch, P., and G. Goertz. 1986. "Factors of Urbanisation in the Nineteenth Century Developed Countries: A Descriptive and Econometric Analysis." Urban Studies 23:285-305.

Bell, D. A. 2008. China's New Confucianism: Politics and Everyday Life in a Changing Society. Princeton, N): Princeton University Press.

Bell, D. A. and Chaibong, H., eds. 2003. Confucianism for the Modern World. Cambridge: Cambridge University Press.

Black, E. C. 1963. The Association: British Extraparliamentary Political Organization 1769-1793. Cambridge, MA: Harvard University Press.

Branigan, T. 2010. “Beijing Marks Confucius’s Happy Return, Aged 2561.” The Guardian September 29.

Brown, K. 2011. Ballot Box China: Grassroots Democracy in the Final Major One-Party State. London: Zed Books.

Chi-Fung, J. W. 2014. “Taking Back Hong Kong's Future.” The New York Times, October 29.

Cho, Y. N. 2009. "Democracy with Chinese Characteristics? A Critical Review from a Developmental State Perspective." Issues and Studies 45:71-106.

Chung, J. H., H. Lai, and M. Xia. 2006. "Mounting Challenges to Governance in China: Surveying Collective Protestors, Religious Sects and Criminal Organizations.” China Journal 56:1-31. 
Clapp, B. W. 1994. An Environmental History of Britain Since the Industrial Revolution. London: Longman.

Clark, P. 2000. British Clubs and Societies 1580-1800. Oxford: Oxford University Press.

Crafts, N. F. R. 1985. British Economic Growth during the Industrial Revolution. Oxford: Oxford University Press.

Davis, M. T. 2005. "Prosecution and Radical Discourse during the 1790s: The Case of the Scottish Sedition Trials." International Journal of the Sociology of Law 33:148-58.

Davis, M. T. 2008. "The Mob Club? The London Corresponding Society and the Politics of Civility in the 1790s." In Unrespectable Radicals? Popular Politics in the Age of Reform, edited by M. T. Davis and P. A. Pickering, 21-40. Aldershot: Ashgate.

Davis, B. 2013. "World Bank Presses China on Urbanization Plan." The Wall Street Journal, September 18.

Dikötter, F. 2008. The Age of Openness: China before Mao. Hong Kong: Hong Kong University Press.

Doolittle, I. 1982. The City of London and Its Livery Companies. Dorchester: Gavin Press.

Ertman, T. 2010. "The Great Reform Act of 1832 and British Democratization." Comparative Political Studies 43:1000-22.

Evans-Pritchard, A. 2013. “China Embraces 'British Model', Ditching Mao for Edmund Burke.” The Telegraph (London), September 8.

Fan, R., ed. 2011. The Renaissance of Confucianism in Contemporary China. Dordrecht: Springer.

Fenby, J. 2014. Will China Dominate the 21st Century? Cambridge: Polity Press.

Franklin, B. 1907. The Writings of Benjamin Franklin, vol. 10, edited by A. H. Smyth. New York: Macmillan.

Hammond, J. L., and B. Hammond. 1987. The Village Labourer 1760-1832. Stroud: Allan Sutton. Harvey, B. 2013. China in Space: The Great Leap Forward. New York: Springer-Verlag.

Hobsbawm, E. J. 1968. Industry and Empire: An Economic History of Britain Since 1750. London: Weidenfeld and Nicolson.

Huang, X. 2011. "Car Ownership Modeling and Forecasts for China." MSc thesis, Michigan Technology University.

Inglehart, R. 1977. The Silent Revolution: Changing Values and Political Styles among Western Publics. Princeton, NJ: Princeton University Press.

Jacques, M. 2012. When China Rules the World: The End of the Western World and the Birth of a New Global Order. New York: Penguin.

Jin, L., and M. Cortazzi. 2006. "Changing Practices in Chinese Cultures of Learning." Language, Culture \& Curriculum 19:5-20.

Kaiman, J. 2013. “Inside China's ‘Cancer Villages'.” The Guardian, June 5.

Kaiman, J. 2014. “Hong Kong Protests Bring Crisis of Confidence for Traditional Media." The Guardian, October 29.

King, G., Pan, J., and Roberts, M. E. 2013. "How Censorship in China Allows Government Criticism but Silences Collective Expression." American Political Science Review 107:1-18.

Kristof, N. D. 2011. "Where China Outpaces America." The New York Times, April 30.

Lam, W. 2011. "Intra-Party Democracy with Chinese Characteristics." In Whither China's Democracy? Democratization in China Since the Tiananmen Incident, edited by J. Cheng, 33-64. Hong Kong: City University of Hong Kong Press.

Li, J. 2013. "China's Industrial Growth a 'Threat to Resources'." South China Morning Post, August 3. 
Lincoln, T. 2012. "China: Revolution in the Streets." History Today 62 (8):44-6.

Macleod, C. 2012. “China's Rapid Industrialization Fuels More Protests.” USA Today, July 29. Maddison, A. 2007. The World Economy. Paris: Development Centre Studies.

Needham, J. 1956. Science and Civilization in China. Cambridge: Cambridge University Press. Neeson, J. M. 1993. Commoners: Common Right, Enclosure and Social Change in England, 17001820. Cambridge: Cambridge University Press.

O'Gorman, F. 1989. Voters, Patrons and Parties: The Unreformed Electoral System of Hanoverian England 1734-1832. Oxford: Oxford University Press.

Page, J., B. Davis, and J. T. Areddy. 2012. “China Turns Predominantly Urban.” The Wall Street Journal, January 18.

Pope, C. A., and D. W. Dockery. 2013. "Air Pollution and Life Expectancy in China and Beyond." Proceedings of National Academy of Sciences of the United States of America 110:12861-2.

Randall, A. 2006. Riotous Assemblies: Popular Protest in Hanoverian England. Oxford: Oxford University Press.

Rostow, W. W. 1960. The Stages of Economic Growth. Cambridge: Cambridge University Press.

Saich, T. 2011. “Chinese Governance Seen through the People's Eyes," East Asia Forum, July 24. http://www.eastasiaforum.org/2011/07/24/chinese-governance-seen-through- thepeople-s-eyes/

Siciliano, G. 2013. The Social and Environmental Implications of Urbanization Strategies and Domestic Land Grabbing in China: The Case of Chongming Island. The Hague: The Land Deal Politics Initiative.

Simmons, I. G. 2001. An Environmental History of Great Britain. Edinburgh: Edinburgh University Press.

State Council Information Office. 2005. "Building of Political Democracy in China." http://www. china.org.cn/english/2005/Oct/145718.htm

Tharoor, I. 2014. "Hong Kong Politician Likens Protestors to American Slaves." The Sydney Morning Herald, November 1.

Thompson, E. P. 1963. The Making of the English Working Class. London: Victor Gollancz.

Tisdell, C. 2009. "Economic Reform and Openness in China: China's Development Policies in the Last 30 Years." Economic Analysis \& Policy 39:271-94.

Wang, H., and C. Wang. 2013. "Municipal Solid Waste Management in Beijing: Characteristics and Challenges." Waste Management \& Research 31:67-72.

Werbel, A. 2013. Lessons from China: America in the Hearts and Minds of the World's Most Important Rising Generation. North Charleston, SC: Creatspace.

Womack, B. 2005. "Democracy and the Governing Party: A Theoretical Perspective." Journal of Chinese Political Sciences 10:23-42.

Yang, Y. 2013. "Youth Urged to Contribute to Realization of 'Chinese Dream'.” http://news. xinhuanet.com/english/china/2013-05/04/c_132359537.htm

Zhao, Y., and C. Webster. 2011. "Land Dispossession and Enrichment in China's Suburban Villages." Urban Studies 48:529-51.

Zhou, S. 2012. Trends in China's Political Reform. Brisbane: Griffith Asia Institute. 